\title{
Evaluasi Manajemen Keamanan Informasi Menggunakan Indeks KAMI Berdasarkan ISO/IEC 27001:2013 pada Politeknik Ilmu Pelayaran Semarang
}

\author{
Evaluation of Information Security Management Using \\ KAMI Based on ISO / IEC 27001: 2013: The case of Politeknik Ilmu Pelayaran \\ Semarang
}

\author{
Desy Dwi Prasetyowati ${ }^{1}$, Indra Gamayanto ${ }^{2}$, Sasono wibowo ${ }^{3}$, Suharnawi ${ }^{4}$ \\ 1,2,3,4Universitas Dian Nuswantoro; Jalan Imam Bonjol Nomor 27, 50131, (024) 3517261 \\ Jurusan Sistem Informasi, FIK UDINUS, Semarang \\ e-mail: ${ }^{1} 112201405095 @$ mhs.dinus.ac.id, 2indra.gamayanto@dsn.dinus.ac.id, \\ ${ }^{3}$ sasono.wibowo@dsn.dinus.ac.id, ${ }^{4}$ Suharnawi@dsn.dinus.ac.id
}

\begin{abstract}
Abstrak
Keamanan informasi merupakan hal penting yang harus dimiliki oleh setiap organisasi atau institusi, hal ini berguna untuk mencegah terjadinya kebocoran data. Penelitian ini dilakukan di Politeknik Ilmu Pelayaran Semarang. Masalah yang terdapat di dalam PIP adalah terjadinya kehilangan data dan diretasnya website milik PIP. Hal ini akan dapat mempengaruhi proses bisnis yang terdapat di PIP. Penelitian ini memiliki tujuan untuk melakukan evaluasi terhadap tingkat keamanan informasi yang terdapat di PIP, dimana hal ini menjadi hal yang sangat penting sekali untuk segera dilakukan. Wawancara dilakukan untuk memperoleh datadata yang akurat, di sisi lainnya, kuesiner juga dilakukan untuk memperoleh data yang lebih akurat lagi. Metode yang digunakan untuk penelitian ini adalah Indeks KAMI, yang merupakan sebuah aplikasi untuk mengukur tingkat kematangan dan tingkat kematangan dari keamanan informasi. lebih jauh lagi, metode ini juga disesuaikan dengan standar ISO/IEC 27001:2013, yang dibuat oleh Kementrian Komunikasi Informasi dan Informatika. Hasil yang didapatkan adalah untuk sistem elektronik menghasilkan score 20, tingkat kelengkapan informasi sebesar 238. Hasil ini mengatakan bahwa masih rendahnya tingkat keamanan dan di sini dibutuhkan tingkat kemananan yang lebih tinggi lagi. Oleh sebab itu, PIP perlu melakukan perubahan dan perbaikan pada sistem yang ada dan memerlukan staff yang memiliki kompetensi untuk mengatasi hal tersebut.
\end{abstract}

Kata kunci- Indeks Keamanan Informasi (KAMI), ISO/IEC 27001:2013, Tingkat Kelengkapan, Tingkat Kematangan, Peningkatkan keamanan informasi

\begin{abstract}
Information security is an important thing that must be owned by every organization or institution, this is useful to prevent data leakage. This research was conducted at the Semarang Sailing Science Polytechnic. The problem found in PIP is the loss of data and hacking of PIP's website. This will affect the business processes contained in PIP. This study aims to evaluate the level of security of information contained in PIP, where this is very important to be done immediately. Interviews were conducted to obtain accurate data; on the other hand, questionnaires were also conducted to obtain more accurate data. The method used for this research is the WE Index, which is an application to measure the level of maturity and maturity level of information security. Furthermore, this method is also adjusted to the ISO / IEC 27001: 2013 standard, which was made by the Ministry of Information and Information Communication. The results obtained are for electronic systems to produce a score of 20, the
\end{abstract}


level of completeness of information is 238. This result says that there is still a low level of security and here is a higher level of security. Therefore, PIP needs to make changes and improvements to the existing system and require staffs that have the competence to overcome it.

Keywords - Indeks Keamanan Informasi (KAMI), ISO/IEC 27001:2013, level of completeness, level of maturity

\section{PENDAHULUAN}

Informasi merupakan aset penting yang harus dilindungi keamanannya, usaha yang dilakukan dalam melindungi keamanan informasi yaitu dengan cara memperhatikan aspekaspek keamanan dari semua perangkat pendukung, fasilitas yang terkait pada proses pengolahan informasi, dan jaringan [1, 2]. Hal tersebut perlu diterapkan oleh Polteknik Ilmu Pelayaran (PIP) Semarang. PIP Semarang sendiri mempunyai unit teknologi informatika yang bertugas mengembangkan sistem informasi, melaksanakan urusan pedoman teknis pelaksanaan sistem informasi, pemantauan dan evaluasi pelaksanaan sistem informasi serta melakukan penyajian data dalam bentuk informasi (website). Semua kegiatan teknologi informasi dan sistem informasi dipusatkan dan dikembangkan di unit teknologi informatika.

Keamanan sistem informasi dan jaringan yang ada di PIP Semarang masih terdapat kelemahan yang mempunyai dampak cukup berbahaya. Gangguan keamanan yang pernah terjadi yaitu peretasan pada website PIP Semarang. Hal tersebut membuat terjadinya beberapa masalah salah satunya yaitu hilangnya data-data penting dan tampilan website PIP Semarang menjadi berantakan karena diretas oleh pihak yang tidak bertanggung jawab, sehingga pihak unit teknologi informatika harus melakukan input data dari awal. Peretasan terhadap website PIP Semarang sudah terjadi sebanyak dua kali.

Salah satu usaha yang dilakukan oleh kementrian Kominfo dalam meningkatkan kualitas keamanan informasi pada suatu instansi adalah dengan menciptakan salah satu tools yang digunkan untuk membantu menilai level kematangan serta kelengkapan dalam keamanan informasi yang dinamakan dengan Indeks Keamanan Informasi (KAMI). Indeks KAMI mengacu pada ISO 27001 yang berisi mengenai keamanan informasi. Penilaian Indeks KAMI lebih baik dilakukan secara berkala dalam jangka waktu tertentu sebagai tools untuk melaksanakan pengamatan ulang kesiapan keamanan informasi serta mengukur kesuksesan gagasan perbaikan yang diimplementasikan, dengan pencapaian tingkat kelengkapan dan kematangan tertentu. Pada kenyataannya penilaian keamanan informasi yang ada di PIP Semarang belum pernah dilakukan sama sekali, sedangkan di unit teknologi informasi pada PIP Semarang masih belum ada bagian khusus yang melakukan penilaian keamanan informasi menggunakan Indeks KAMI.

\section{METODE PENELITIAN}

Dalam melakukan penelitian ini, metode penelitian yang digunakan menggunakan Indeks Keamanan Informasi (KAMI) berdasarkan ISO/IEC 27001:2013 sebagai kerangka penelitian untuk mengolah hasil analisa dari wawancara tentang keamanan informasi[3]. Indeks KAMI versi 3.1 merupakan alat yang dipakai untuk menilai tingkat kematangan, tingkat kelengkapan penerapan ISO/IEC 27001:2013 serta gambaran tata kelola keamanan informasi pada suatu organisasi maupun perusahaan. Indeks KAMI dibuat oleh kementrian Kominfo. Berikut ini merupakan gambaran proses dari evaluasi indeks Kemanan Informasi: 


\section{Mendefisinikan ruang lingkup}
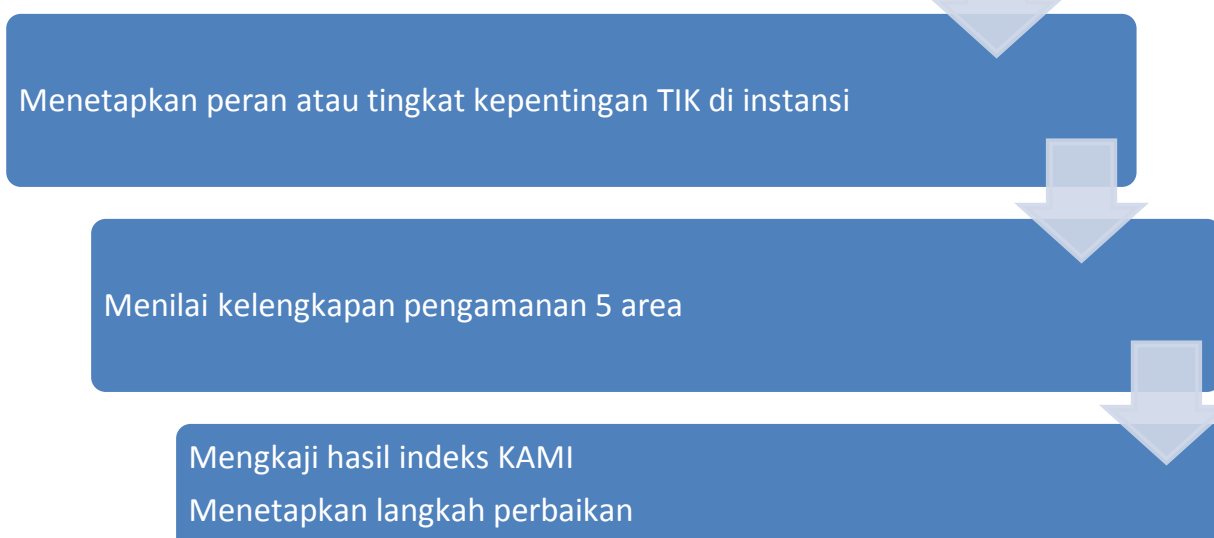

Penetapan prioritas

Mengkaji ulang tingkat kelengkapan dan kematangan dengan indeks KAMI

Gambar 1. Proses indeks keamanan informasi

Alat evaluasi Indeks KAMI dianjurkan untuk dilakukan oleh pejabat yang secara langsung bertanggung jawab dan berwenang untuk mengelola keamanan informasi di seluruh cakupan instansinya. Evaluasi yang dilakukan dengan menggunakan indeks KAMI ini mencakup 5 target area, yaitu tata kelola keamanan informasi, pengelolaan risiko keamanan informasi, kerangka kerja keamanan informasi, pengelolaan aset informasi, dan teknologi dan keamanan informasi

Sebelum dilakukan proses penilaian secara kuantitatif, maka dilakukan proses klasifikasi terlebih dahulu terhadap kategori Sistem Elektronik. Tujuan dari penilaian kategori Sistem Elektronik ini adalah untuk mengelompokkan instansi kedalam ukuran tertentu.

Tabel 1. Nilai kategori sistem elekronik

\begin{tabular}{ll}
\hline Rendah & $10-15$ \\
Tinggi & $16-34$ \\
Strategies & $35-50$ \\
\hline
\end{tabular}

Setelah menklasifikasikan Peran SE di instansi terkait, maka akan dilakukan penilaian terhadap kelima area yang ada di Indeks KAMI versi 3.1. Hasil penilaian menggunakan Indeks KAMI versi 3.1 akan digambarkan kedalam diagram yang berbentuk jaring laba-laba (spider chart) dengan 5 area utama. Dalam jaring laba-laba tersebut juga akan dilihat tentang nilai Indeks KAMI dengan kepatuhan terhadap ISO/IEC 27001:2013.

Semakin tinggi ketergantungan sebuah instansi terhadap peran SE, maka semakin banyak bentuk pengamanan yang diperlukan dan harus diterapkan sampai tahap tertinggi. Pada gambar dibawah ini akan menunjukkan skor akhir yang akan disesuaikan dengan status kesiapan instansi terkait mengenai keamanan informasinya. 


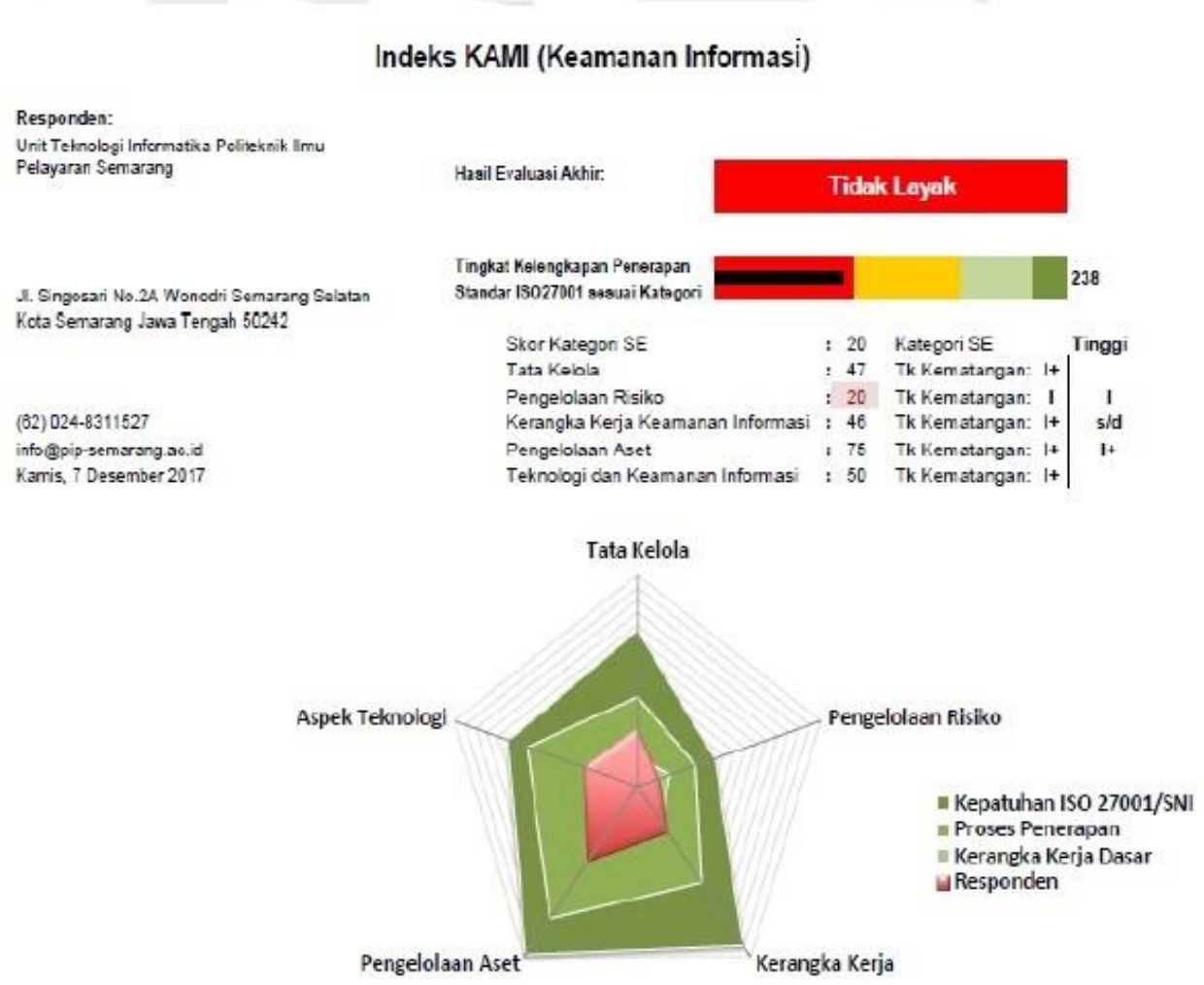

Gambar 2. Dashboard Hasil Evaluasi Indeks KAMI

Tabel 2. Matriks kategori sistem elektronik dan status kesiapan

\begin{tabular}{|c|c|c|c|c|}
\hline \multicolumn{4}{|c|}{ KATEGORI SISTEM ELEKTRONIK } & \multirow[b]{2}{*}{ Status Kesiapan } \\
\hline \multicolumn{2}{|c|}{ Rendah } & \multicolumn{2}{|c|}{ Skor Akhir } & \\
\hline \multirow{4}{*}{10} & \multirow{4}{*}{15} & $\mathbf{0}$ & 174 & Tidak Layak \\
\hline & & 175 & 312 & Perlu Perbaikan \\
\hline & & 313 & 535 & Cukup \\
\hline & & 536 & 645 & Baik \\
\hline \multicolumn{2}{|l|}{ Tinggi } & \multicolumn{2}{|c|}{ Skor Akhir } & Status Kesiapan \\
\hline \multirow{4}{*}{16} & \multirow{4}{*}{34} & 0 & 272 & Tidak Layak \\
\hline & & 273 & 455 & Perlu Perbaikan \\
\hline & & 456 & 583 & Cukup \\
\hline & & 584 & 645 & Baik \\
\hline \multicolumn{2}{|c|}{ Strategis } & \multicolumn{2}{|c|}{ Skor Akhir } & Status Kesiapan \\
\hline \multirow{4}{*}{35} & \multirow{4}{*}{50} & 0 & 333 & Tidak Layak \\
\hline & & 334 & 535 & Perlu Perbaikan \\
\hline & & 536 & 609 & Cukup \\
\hline & & 610 & 645 & Baik \\
\hline
\end{tabular}

\section{HASIL DAN PEMBAHASAN}

Di zaman yang serba teknologi seperti ini, suatu instansi manapun baik itu pemerintah atau swasta pastinya dalam pengolahan suatu data, menerima informasi dan lain sebagainya membutuhkan suatu keamanan yang benar-benar harus bisa menjaganya, baik dari segi keamanan untuk datanya tersebut sekaligus untuk penggunaannya $[4,5]$. Keamanan suatu data pada sistem sangatlah diperlukan sekali bagi para pembisnis pastinya, mau tidak mau suatu instansi manapun harus dapat beradaptasi dengan cepat, kebutuhan akan informasi teknologi dan koneksi data [6,7]. Sistem yang dapat diakses dengan availability yang tinggi saat ini dibutuhkan, openness dan terdistribusi pasti sudah menjadi kewajiban atau keharusan untuk 
sistem yang terintegrasi, karena dengan adanya server yang dikoneksikan terus menerus ke suatu jaringan mau tidak mau akan membuka lubang-lubang sistem keamanan, dan sebenarnya tidak ada sistem yang sempurna, akan tetapi kita hanya bisa meningkatkan dari status tidak aman menjadi relatif lebih aman, karena banyak sekali cara atau metode untuk lubang-lubang keamanan yang dapat ditembus [8]. Oleh sebab itu, Semakin meningkatnya pemanfaatan teknologi informasi dalam berbagai bidang maka resiko ancaman terhadap keamanan informasi juga terus meningkat. Dari berbagai sumber indikasi semakin meningkatnya ancaman terhadap keamanan informasi dapat dilihat baik dari jumlah maupun dari tingkat kecanggihannya [9, 10]. Kerugian finansial yang ditimbulkan sangat besar yang terjadi dalam berbagai bentuk seperti hilangnya pendapatan, besarnya biaya perbaikan, hilangnya data dan kepercayaan pelanggan serta bentuk-bentuk kerugian lain. Kenyataan ini mengharuskan pengguna teknologi informasi baik sebagai pribadi maupun institusi harus siap menghadapi ancaman keamanan informasi ini $[11,12]$. Lebih jauh lagi, meningkatkan keamanan data dan inovasi pada sistem-sistem yang sudah lama akan dapat mampu menghadapi era globalisasi saat ini secara signifikan [13, 14]. Sebagai contoh, untuk dapat meningkatkan layanan yang maksimum, Politeknik ilmu pelayaran semarang perlu meningkatkan kompetensi dan penyediaan sumber daya manusia yang handal $[15,16]$, di sisi lainnya, infrastruktur teknologi informasi juga perlu diperhatikan dan dengan seksama harus dapat ditingkatkan agar dapat menghadapi perubahan-perubahan yang drastis. Hasil dari analisis data dan metode yang telah diterapkan dapat dijelaskan sebagai berikut:

A. Hasil Skor Kepentingan Pengguna Sistem Elektronik pada Politeknik Ilmu Pelayaran Semarang

Dari hasil penilaian tingkat kepentingan penggunaan Sistem Elektronik di Politeknik Ilmu Pelayaran (PIP) Semarang didapatkan skor sebesar 20 dan dalam kategori tinggi. Berdasarkan tabel tingkat kematangan Indeks KAMI dimana kategori Tinggi berkisar antara skor 16 sampai dengan 34. Evaluasi ini memberikan gambaran pihak instansi telah menyadari betul bahwa peran sistem elektronik sangat memberikan kemudahan bagi para staff untuk membantu menjalankan proses bisnis.

Tabel 3. Hasil penilaian penggunaan system elektronik

\begin{tabular}{|c|c|c|c|}
\hline \multicolumn{4}{|c|}{ Bagian I: Kategori Sistem Elektronik } \\
\hline \multicolumn{4}{|c|}{ Bagian ini mengevaluasi tingkat atau kategori sistem elektronik yang digunakan } \\
\hline \multirow{2}{*}{\multicolumn{2}{|c|}{$\begin{array}{l}\text { [Kategori Sistem Elektronik] Rendah, tinggi, strategis. } \\
\text { c) Tidak tersedianya layanan publik atau proses } \\
\text { penyelenggaraan negara dalam } 1 \text { kabupaten/kota } \\
\text { atau lebih }\end{array}$}} & Status & Skor \\
\hline & & & \\
\hline \multirow[t]{2}{*}{1.10} & $\begin{array}{l}\text { Potensi kerugian atau dampak negatif dari insiden } \\
\text { ditembusnya keamanan informasi Sistem Elektronik } \\
\text { (sabotase, terorisme) } \\
\text { a) Menimbulkan korban jiwa } \\
\text { b) Terbatas pada kerugian finansial } \\
\text { c) Mengakibatkan gangguan operasional sementara } \\
\text { (tidak membahayakan dan merugikan finansial) }\end{array}$ & $\mathrm{C}$ & 1 \\
\hline & Skor penetapan Kategori Sistem Elektronik & 20 & \\
\hline
\end{tabular}

B. Penilaian ke 5 Area Kesiapan Keamanan Informasi di Politeknik Ilmu Pelayaran Semarang 
Setiap kategori pertanyaan pada ke 5 area kesiapan keamanan informasi memiliki nilai skor yang berbeda. Berikut adalah pemetaan skor Indeks KAMI berdasarkan masing masing kategori:

Tabel 4. Matriks skor pemetaan pengamanan

\begin{tabular}{|l|c|c|c|}
\cline { 2 - 4 } \multicolumn{2}{l|}{} & \multicolumn{3}{c|}{ Kategori Pengamanan } \\
\hline Status Pengamanan & 1 & 2 & 3 \\
\hline Tidak Dilakukan & 0 & 0 & 0 \\
\hline Dalam Perencanaan & 1 & 2 & 3 \\
\hline Dalam Penerapan atau Diterapkan Sebagian & 2 & 4 & 6 \\
\hline Diterapkan Secara Menyeluruh & 3 & 6 & 9 \\
\hline
\end{tabular}

Berikut adalah salah satu contoh tabel dari penilaian dengan menggunakan Indeks KAMI yang telah dilakukan pada Politeknik Ilmu Pelayaran Semarang.

Tabel 5. Hasil penilaian tata kelola keamanan informasi

\begin{tabular}{|c|c|c|c|c|c|}
\hline \multicolumn{6}{|c|}{ Bagian II: Tata Kelola Keamanan Informasi } \\
\hline \multicolumn{6}{|c|}{$\begin{array}{l}\text { Bagian ini mengevaluasi kesiapan bentuk tata kelola keamanan informasi beserta } \\
\text { Instansi atau fungsi, tugas dan tanggung jawab pengelola keamanan informasi. }\end{array}$} \\
\hline \multicolumn{4}{|c|}{$\begin{array}{l}\text { [Penilaian] Tidak dilakukan, dalam perencanaan, } \\
\text { dalam penerapan atau diterapkan sebagian, } \\
\text { diterapkan secara menyeluruh. }\end{array}$} & Status & Skor \\
\hline & & & $\begin{array}{l}\text { mengevaluasi pencapaiannya secara } \\
\text { rutin, menerapkan langkah perbaikan } \\
\text { untuk mencapai sasaran yang ada, } \\
\text { termasuk pelaporan statusnya kepada } \\
\text { pimpinan Instansi? }\end{array}$ & & \\
\hline 2.21 & IV & 3 & $\begin{array}{l}\text { Apakah Instansi anda sudah } \\
\text { mengidentifikasi legislasi, perangkat } \\
\text { hukum dan standar lainnya terkait } \\
\text { keamanan informasi yang harus } \\
\text { dipatuhi dan menganalisa tingkat } \\
\text { kepatuhannya? }\end{array}$ & $\begin{array}{l}\text { Dalam } \\
\text { Perencanaan }\end{array}$ & 0 \\
\hline 2.22 & IV & 3 & $\begin{array}{lr}\text { Apakah Instangi anda sudah } \\
\text { mendefinisikan kebijakan dan } \\
\text { langkah penanggulangan insiden } \\
\text { keamanan informasi } \\
\text { menyangkut pelanggaran hukum } \\
\text { (pidana dan perdata)? }\end{array}$ & $\begin{array}{c}\text { Dalam } \\
\text { Perencanaan }\end{array}$ & 0 \\
\hline & & & Total Nilai Evaluasi Tata Kelola & 47 & \\
\hline
\end{tabular}


Untuk mengetahui status kelengkapan pada bagian ini yaitu, dengan cara membandingkan total skor tahap penerapan 1 dan 2 dengan batas skor minimal tahap penerapan 3. Batas skor minimal tersebut sudah ditentukan oleh indeks KAMI pada bagian Tata Kelola yaitu berjumlah 48 . Diketahui total skor pada tahap penerapan 1 dan 2 berjumlah 47, yang artinya skor tersebut tidak melebihi jumlah skor tahap penerapan 3. Maka bagian Tata Kelola disimpulkan masih menduduki Tingkat Kematangan I+.

C. Analisis Hasil Akhir Penilaian Indeks KAMI

Berikut ini merupakan hasil dari penilaian indeks KAMI pada Politeknik Ilmu Pelayaran Semarang. Hasil tampilan dari dashboard indeks KAMI yang diperoleh adalah sebagai berikut :

\section{Indeks KAMI (Keamanan Informasi)}

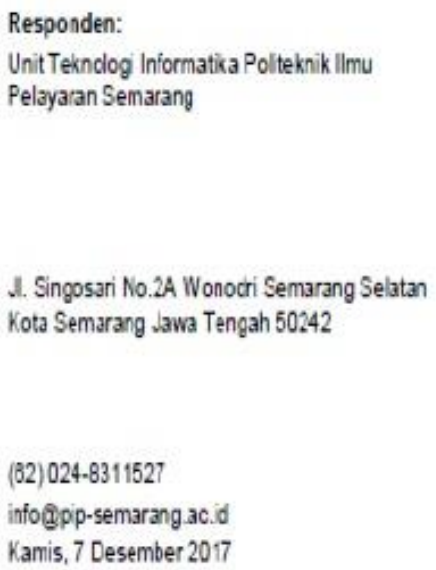

Hagil Evaluasi Akhir:

\section{Tidak Layak}

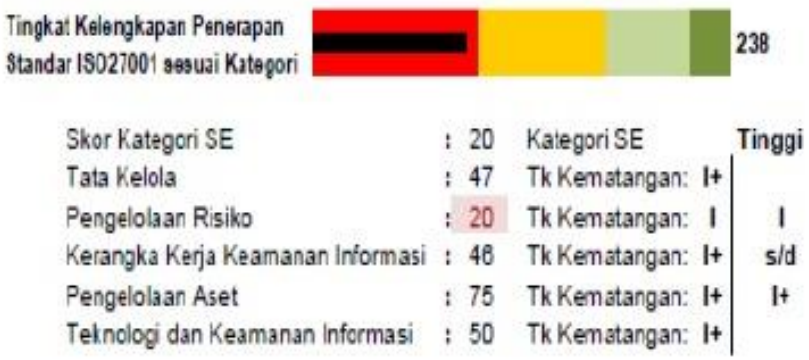

Gambar 3. Dashboard Hasil Evaluasi Indeks KAMI PIP Semarang

Dashboard diatas merupakan gambaran secara keseluruhan dari penilaian yang telah dilakukan dengan menggunakan indeks KAMI versi 3.1. Dari dashboard diatas, dapat dilihat bahwa tingkat kematangan keamanan informasi di Politeknik Ilmu Pelayaran Semarang masih sangat kurang, yaitu tingkat I+ dengan nilai sebesar 238. Dapat dilihat pada radar chart dashboard tersebut bahwa hampir seluruh area yang dinilai dalam indeks KAMI belum terpenuhi dan sesuai dengan ISO 27001. Jika dilihat dibagian radar chart dashboard, hasil yang didapat hanya sebatas sampai kategori kerangka kerja dasar (kondisi awal).

Dari gambar diatas dapat terlihat jika nilai indeks KAMI5 yang telah dicapai tergolong tidak layak, yaitu hanya mencapai tingkat I+. Nilai yang didapatkan masih dikatakan tidak layak karena nilai yang dicapai tidak sesuai dengan kepentingan penggunaan sistem elektronik yang digunakan pada Politeknik Ilmu Pelayaran Semarang yaitu mencapai tingkat tinggi. Untuk tingkat kematangan setiap area yang telah dinilai dalam indeks KAMI versi 3.1 masih sangat kurang. Berikut ini adalah uraian dari tingkat kematangan kelima area yang telah dinilai sebelumnya: 
Tabel 6. Tingkat Kematangan Kelima Area

\begin{tabular}{|c|c|c|c|c|c|}
\hline & Tata Kelola & $\begin{array}{l}\text { Pengelolaan } \\
\text { Risiko }\end{array}$ & $\begin{array}{c}\text { Kerangka } \\
\text { Kerja }\end{array}$ & $\begin{array}{c}\text { Pengelolaan } \\
\text { Aset }\end{array}$ & $\begin{array}{c}\text { Aspek } \\
\text { Teknologi }\end{array}$ \\
\hline \multicolumn{6}{|c|}{ Tingkat Kematangan II } \\
\hline Status & I+ & No & $\mathrm{I}+$ & I+ & I+ \\
\hline \multicolumn{6}{|c|}{ Tingkat Kematangan III } \\
\hline Status & No & No & No & No & No \\
\hline Validitas & No & No & No & No & No \\
\hline \multicolumn{6}{|c|}{ Tingkat Kematangan IV } \\
\hline Status & No & No & No & No & No \\
\hline Validitas & No & No & No & No & No \\
\hline \multicolumn{6}{|c|}{ Tingkat Kematangan V } \\
\hline Status & No & No & No & No & No \\
\hline Validitas & No & No & No & No & No \\
\hline Status Akhir & I+ & I & I+ & I+ & I+ \\
\hline
\end{tabular}

Urutan tingkat kematangan dari terendah sampai ke tertinggi adalah I - V. Batasan minimal yang harus dicapai supaya dapat melakukan sertifikasi ISO adalah III+, sedangkan untuk saat ini tingkat kematangan pada Politeknik Ilmu Pelayaran Semaranag hanya dibatas I I+. Tingkat kematangan tersebut menunjukkan bahwa posisi Politeknik Ilmu Pelayaran Semarang adalah sebagai berikut ini:

Tabel 7. Tingkatan Kondisi

\begin{tabular}{ccc}
\hline Tingkatan & Kondisi \\
\hline I & Kondisi awal \\
II & Penerapan kerangka kerja dasar \\
III & Terdefinisi dan konsisten \\
IV & Terkelola dan terukur \\
V & Optimal \\
\hline
\end{tabular}

Dari tabel diatas dapat diketahui bahwa tingkat kematangan pada Politeknik Ilmu Pelayaran Semarang berada dibatas I - I+ yang artinya masih dalam kondisi awal.

D. Saran Perbaikan 5 Area Keamanan Informasi

Setelah melakukan penilaian dengan indeks KAMI versi 3.1 dan mengetahui hasil dari setiap area yang terdapat dalam indeks KAMI versi 3.1, maka tahap selanjutnya adalah membuat saran perbaikan pada setiap bagian yang masih kurang baik. Berikut ini adalah saran perbaikan yang dibuat per masing-masing area yang ada dengan table berisikan pertanyaan, status, nilai, dan saran perbaikan. 
Tabel 8. Saran perbaikan area tata kelola keamanan informasi

\begin{tabular}{|c|c|c|c|}
\hline No & Pertanyaan & Status & Nilai \\
\hline 2.2 & $\begin{array}{l}\text { Apakah Instansi anda memiliki } \\
\text { fungsi atau bagian yang secara } \\
\text { spesifik mempunyai tugas dan } \\
\text { tanggungjawab mengelola keamanan } \\
\text { informasi dan menjaga } \\
\text { kepatuhannya? }\end{array}$ & & 1 \\
\hline \multicolumn{4}{|c|}{$\begin{array}{l}\text { Saran Perbaikan } \\
\text { Bagian yang mempunyai tugas dan tanggungjawab dalam mengelola keamanan } \\
\text { informasi sangat penting dalam suatu instansi. Karena itu, secara berkala perlu } \\
\text { dilakukannya suatu evaluasi risiko keamanan informasi yang mengidentifikasi } \\
\text { aset informasi kritis (diantaranya sistem, jaringan, data), ancaman terhadap aset } \\
\text { kritis, kerawanan asset, dan risiko. Untuk dapat membangun dan menerapkan } \\
\text { sistem keamanan informasi yang baik, sebaiknya organisasi memulainya dari } \\
\text { upaya melakukan kajian terhadap resiko - resiko keamanan yang mungkin } \\
\text { timbul. Kajian yang dimaksud dapat diterapkan dalam tingkatan organisasi, } \\
\text { maupun pada tataran sub bagian atau fungsi organisasi tertentu, seperti sistem } \\
\text { informasi, komponen, layanan, dan lain sebagainya yang sesuai dengan skala } \\
\text { prioritas yang ada. }\end{array}$} \\
\hline & $\begin{array}{l}\text { an resiko yang dimaksud merupakan suat } \\
\text { Identifikasi terhadap kejadian - kejadi } \\
\text { keamanan informasi perusahaan dan }\end{array}$ & pendekatan siste & $\begin{array}{l}\text { lari proses: } \\
\text { lengancam }\end{array}$ \\
\hline
\end{tabular}

\section{KESIMPULAN}

Berikut ini merupakan kesimpulan dari penelitian yang telah dilakukan terkait penilaian manajemenen keamanan informasi pada Politeknik Ilmu Pelayaran Semarang dengan menggunakan Indeks Keamanan Informasi (KAMI) adalah sebagai berikut:

1. Hasil dari penilaian tingkat penggunaan Sistem Elektronik adalah sebesar 20, dari jumlah total keseluruhan sebesar 50. Hal ini menunjukkan bahwa Politeknik Ilmu Pelayaran sudah termasuk dalam kategori tinggi dalam kebutuhan penggunaan system elektronik yang artinya penggunaan sistem elektronik merupakan bagian yang tidak terpisahkan dari proses bisnis yang berjalan.

2. Hasil keseluruhan dari penilaian kelima area dalam Indeks KAMI adalah sebesar 238 dari jumlah total keseluruhan sebesar 645 dan berada pada level I-I+ dimana level ini masih berada pada kondisi awal penerapan keamanan informasi. Hal tersebut menunjukkan bahwa mulai adanya pemahaman mengenai perlunya pengelolaan kemanan informasi akan tetapi penerapan langkah pengamanan masih belum teratur serta tidak adanya pengawasan dari pihak-pihak yang terlibat dan belum menyadari tanggung jawab atas tugas mereka, pihak pengelola keamanan informasi juga belum menyadari tanggungjawabnya sehingga diperlukannya suatu perbaikan. 
3. Tingkat kematangan per area akan dijabarkan sebagai berikut:

Area tata kelola keamanan informasi berada pada tingkat I+, area pengelolaan risiko keamanan informasi pada tingkat I, area kerangka kerja pengelolaan keamanan informasi ditingkat I+, area pengelolaan aset informasi berada pada tingkat I+, serta area teknologi dan keamanan informasi pada tingkat I+.

\section{SARAN}

Saran berdasarkan penelitian yang dilakukan oleh penulis sebagai bentuk perbaikan penelitian tugas akhir ini antara lain:

1. Dibangunnya kesadaran dari para staff atau pegawai Politeknik Ilmu Pelayaran Semarang terkait keamanan informasi. Para staff harus menyadari pentingnya suatu keamanan informasi untuk melindungi seluruh aspek yang berkaitan dengan informasi dalam mendukung jalannya proses bisnis.

2. Dalam melakukan penilaian perhatikanlah cara pengujian pada pertanyaan yang membutuhkan jenis penilaian lebih dari satu, maka lakukan pengujian terhadap kualitas dan juga kuantitas dengan cara melakukan penilaian melalui kuisioner dan penelitian langsung pada item yang dinilai, agar nilai yang diberikan pada pertanyaan tersebut benar-benar valid.

\section{DAFTAR PUSTAKA}

[1] I. Gamayanto, "Porter S Five Forces Model Scott Morton S Five Forces Model Bakos Treacy Model Analyzes Strategic Information Systems Management," J. Inform., vol. 5, no. 2, p. pp.127-134, 2004.

[2] I. Gamayanto, "Analysis of Wollongong City Council Using 7S' S of Galliers and Sutherland Methods," comptech J., no. 205, pp. 205-213, 2017.

[3] S. Kasus, K. Provinsi, J. Timur, E. R. Pratama, and A. R. Perdanakusuma, "Evaluasi Tata Kelola Sistem Keamanan Teknologi Informasi Menggunakan Indeks KAMI dan ISO 27001," J. Pengemb. Teknol. Inf. dan Komput., vol. 2, no. 11, pp. 5911-5920, 2018.

[4] A. R. Martínez-lorente, F. De Ciencias, D. Empresa, P. A. Xiii, and M. Martínez-costa, "ISO 9000 \& TQM: SUBSTITUTES OR COMPLEMENTARIES? AN EMPIRICAL STUDY IN INDUSTRIAL COMPANIES."

[5] B. Neyestani, J. Berlin, and P. Juanzon, "ISO 9001 Standard and Organization â€ $€^{\mathrm{TM}} \mathrm{s}$ Performance: A Literature Review ISO 9001 Standard and Organization $\hat{a} €^{\mathrm{TM}} \mathrm{s}$ Performance : A Literature Review," Int. J. Adv. Multidiscip. Res, vol. 4, no. 2, pp. 6-13, 2017.

[6] P. Domingues, "Iso 9001:2015 edition- management, quality and value," Int. J. Qual. Res., vol. 11, no. 1, pp. 149-158, 2015.

[7] M. Bakator and D. Ćoćkalo, "IMPROVING BUSINESS PERFORMANCE WITH ISO 9001: A REVIEW OF LITERATURE AND BUSINESS PRACTICE," Eur. J. Appl. Econ., vol. 15, no. 1, pp. 83-93, 2018.

[8] D. A. Kumar and V. Balakrishnan, "A Study on ISO 9001 Quality Management System Certifications - Reasons behind the Failure of ISO Certified Organizations," Glob. J. Manag. Bus. Res., vol. 11, no. 9, 2011.

[9] N. Hidayati, "KAJIAN TATA KELOLA IT BERDASARKAN INDEKS KAMI PADA UNIVERSITAS PAKUAN BOGOR,” J. Paradig., vol. XVI, no. 2, 2014. 
[10] O. A. Okwiri and I. M. Mbeche, "ISO 9001 Certification Status and Organizational Quality Maturity Mixed findings from Quality Management and Performance studies," Int. J. Bus. Soc. Sci., vol. 5, no. 10, pp. 201-211, 2014.

[11] S. M. ARIF, "KAJIAN KEAMANAN TEKNOLOGI DAN SISTEM INFORMASI DENGAN MENGGUNAKAN METODE INDEKS KAMI: STUDI KASUS PADA PERUSAHAAN XYZ," Fakt. Exacta, vol. 8, no. 2, pp. 169-180, 2015.

[12] F. A. Basyarahil, H. M. Astuti, and C. Hidayanto, "Evaluasi Manajemen Keamanan Informasi Menggunakan Indeks Keamanan Informasi Direktorat Pengembangan Teknologi dan Sistem Informasi ( DPTSI ) ITS Surabaya," J. Tek. ITS, vol. 6, no. 1, 2017.

[13] F. Ekonomi and U. Kanjuruhan, "KEPUASAN PELANGGAN PADA PERUSAHAAN MANUFAKTUR,” J. Ekon. Mod., vol. 9000, pp. 36-56, 2007.

[14] I. Afrianto and T. Suryana, "Pengukuran dan Evaluasi Keamanan Informasi Menggunakan Indeks KAMI - SNI ISO / IEC 27001 : 2009 Studi Kasus Perguruan Tinggi X," Ultim. InfoSys, vol. VI, no. 1, pp. 43-49, 2015.

[15] I. K. Dewi, "menggunakan indeks KAMI ( Keamanan Informasi ) PERLINDUNGAN TENAGA USULAN MANAJEMEN RISIKO BERDASARKAN STANDAR SNI ISO / IEC $27001: 2009$ MENGGUNAKAN INDEKS KAMI ( KEAMANAN INFORMASI ) STUDI KASUS: BADAN NASIONAL PENEMPATAN DAN PERLINDUNGAN TENAGA KERJA,” Stud. Inform. J. Sist. Inf., vol. 8, no. 1, pp. 1-7, 2015.

[16] J. J. Tarí, J. F. Molina-azorín, and I. Heras, "Benefits of the ISO 9001 and ISO 14001 standards: A literature review," J. indusrial Eng. Manag., vol. 5, no. 2, pp. 297-322, 2013. 